\title{
The role of lipids in psoriasis
}

\section{Znaczenie lipidów w łuszczycy}

Anna Baran, Paulina Kiluk, Hanna Myśliwiec, Iwona Flisiak

Department of Dermatology and Venereology, Medical University of Białystok, Poland

Klinika Dermatologii i Wenerologii Uniwersytetu Medycznego w Białymstoku, Polska

Dermatol Rev/Przegl Dermatol 2017, 104, 619-635 DOl: https://doi.org/l0.51|4/dr.2017.71834

\author{
CORRESPONDING AUTHOR/ \\ ADRES DO KORESPONDENCJI: \\ dr n. med. Anna Baran \\ Klinika Dermatologii \\ i Wenerologii \\ Uniwersytet Medyczny \\ w Białymstoku \\ ul. Żurawia 14 \\ 15-540 Białystok, Polska \\ tel.: +48608486422 \\ e-mail: aannabaran@wp.pl
}

\begin{abstract}
Psoriasis, affecting 2-4\% of the world's population, is a chronic recurrent inflammatory skin disease. Its multifactorial aetiopathogenesis consists of, for example, abnormal epidermal proliferation, immune disturbances, and genetic, psychosomatic, environmental and hormonal factors. Psoriasis is also considered to be a systemic disorder closely associated with cardiovascular diseases, atherosclerosis, diabetes mellitus, obesity or metabolic syndrome. Lipids have a variety of biological functions. They participate not only in energy storage and expenditure or the formation of cell membranes, but also in inflammatory and metabolic signalling pathways. Disturbances in their homeostasis lead to the development of immunometabolic disorders, including psoriasis. Based on the available literature, this article presents selected molecular and clinical aspects involved in the multidirectional effect of lipids on psoriasis.
\end{abstract}

\section{STRESZCZENIE}

Łuszczyca, która występuje u 2-4\% populacji na świecie, jest przewlekłą i nawrotową chorobą zapalną skóry. Na jej wieloczynnikową etiopatogenezę składają się m.in. nieprawidłowa proliferacja naskórka, zaburzenia immunologiczne, czynniki genetyczne, psychosomatyczne, środowiskowe i hormonalne. Łuszczyca jest również uznawana za schorzenie ogólnoustrojowe, związane z chorobami układu sercowo-naczyniowego, miażdżycą, cukrzycą, otyłością i zespołem metabolicznym. Lipidy pełnią wiele biologicznych funkcji, biorą udział nie tylko w magazynowaniu i wydatkowaniu energii, tworzeniu błon komórkowych, lecz także w zapalnych i metabolicznych szlakach sygnałowych. Zaburzenia ich homeostazy powodują rozwój schorzeń immunometabolicznych, w tym łuszczycy. W niniejszej pracy przedstawiono na podstawie dostępnego piśmiennictwa wybrane aspekty molekularne i kliniczne wielokierunkowego wpływu lipidów na łuszczycę.

Key words: diet, obesity, lipids, psoriasis, metabolic syndrome. Słowa kluczowe: dieta, otyłość, lipidy, łuszczyca, zespół metaboliczny. 


\section{INTRODUCTION}

Psoriasis is a chronic inflammatory skin disease affecting $2-4 \%$ of the general population. The disease has a complex pathogenesis involving, among others, genetic, immune and environmental factors, and abnormal epidermal proliferation. At present, psoriasis is viewed not only as a disease of the skin but, above all, a systemic disorder closely associated with cardiovascular diseases (CVD), diabetes mellitus (DM), metabolic syndrome (MS) and obesity [1, 2]. The life expectancy of patients with psoriasis is on average 5 years shorter than in healthy individuals. The main causes of death are thromboembolic events and myocardial infarction (MI) [3]. The risk of obesity and diabetes in patients with psoriasis is over twice as high as in the general population, and nearly half of them are affected by MS $[2,3]$. The common basis of psoriasis and its comorbidities comprises primarily a metabolically induced inflammatory process called metaflammation, genetic links, often shared disturbed immunological pathways and a range of bioactive substances secreted by the adipose tissue [3-5]. Also important is the so-called "psoriatic march", i.e. a concept of how psoriasis may drive the development of chronic vascular lesions. Chronic inflammation accompanying psoriasis and obesity increases insulin resistance, resulting in endothelial dysfunction and development of atheromatosis, leading to cardiovascular events $[5,6]$.

Lipids have a variety of biological functions. For example, they participate in energy storage and expenditure, formation of cell membranes, and inflammatory and metabolic signalling pathways. Disturbances in lipid homeostasis trigger systemic diseases such as obesity, DM, CVD and MS, but also skin diseases including psoriasis.

Lipid metabolism is a very complex combination of multiple processes taking place in various body organs including the skin, and in blood. The beginnings of research on lipid disorders in the pathogenesis of psoriasis go back to the 1970s, when cholesterol concentrations were quantified. Also noted were differences in phospholipid composition in psoriatic lesions, which was linked to effects on inflammation and parakeratosis. The continuous loss of lipids with scales was suggested to implicate serum lipid disorders $[7,8]$.

Based on the available literature, the present paper outlines selected molecular and clinical aspects related to the role of lipids in the pathogenesis of psoriasis and its links to systemic diseases (fig. 1).

\section{EPIDERMAL LIPIDS}

Stratum corneum serves as a barrier between the external environment and the internal body, and pre-

\section{WPROWADZENIE}

Łuszczyca jest przewlekłą chorobą zapalną skóry, występującą u 2-4\% populacji. W jej złożonej patogenezie biorą udział m.in. czynniki genetyczne, immunologiczne, środowiskowe oraz zaburzona proliferacja naskórka. Obecnie łuszczycę uznaje się nie tylko za chorobę skóry, lecz przede wszystkim za schorzenie ogólnoustrojowe, ściśle związane m.in. z chorobami sercowo-naczyniowymi (cardiovascular disease - CVD), cukrzycą (diabetes mellitus - DM), zespołem metabolicznym (metabolic syndrome - MS) i otyłością [1, 2]. Pacjenci z łuszczycą żyją średnio o 5 lat krócej niż osoby zdrowe. Główną przyczyną zgonów są incydenty zakrzepowo-zatorowe i zawał mięśnia sercowego (myocardial infarction - MI) [3]. Ryzyko wystąpienia otyłości i cukrzycy jest ponad 2-krotnie wyższe u chorych $\mathrm{z}$ łuszczyca, a MS występuje u blisko połowy z nich [2, 3]. Wspólnym podłożem łuszczycy i chorób współistniejących są przede wszystkim metabolicznie wywołany przewlekły proces zapalny, tzw. metaflammation, powiązania genetyczne, często wspólne zaburzone szlaki immunologiczne i liczne bioaktywne substancje wydzielane przez tkankę tłuszczową [3-5]. Nie można pominąć koncepcji ",marszu łuszczycowego", która wyjaśnia rozwój przewlekłych zmian naczyniowych u pacjentów z łuszczycą. Przewlekły proces zapalny istniejący $w$ łuszczycy i otyłości prowadzi do nasilenia insulinooporności i w efekcie do dysfunkcji śródbłonka, miażdżycy i incydentów sercowo-naczyniowych $[5,6]$.

Lipidy odgrywają różne funkcje biologiczne. Biorą udział m.in. w magazynowaniu i wydatkowaniu energii, tworzeniu błon komórkowych, ale również w zapalnych i metabolicznych szlakach sygnałowych. Zaburzenia homeostazy lipidów prowadzą do rozwoju schorzeń ogólnoustrojowych, takich jak otyłość, DM, CVD, MS, oraz chorób skóry, w tym łuszczycy.

Metabolizm lipidów składa się z wielu procesów, które zachodzą w różnych narządach, m.in. w skórze oraz we krwi. Początek badań nad zaburzeniami lipidowymi w patogenezie łuszczycy sięga lat 70 . ubiegłego wieku, kiedy to oceniano ilościowo stężenia cholesterolu. Zwracano również uwagę na odmienny skład fosfolipidów w zmianach łuszczycowych, co wiązano z wpływem na stan zapalny i parakeratozę. Sugerowano, że ciągła utrata lipidów wraz z łuskami implikuje zaburzenia lipidowe w surowicy $[7,8]$.

$\mathrm{W}$ pracy przedstawiono na podstawie danych $\mathrm{z}$ piśmiennictwa wybrane zagadnienia molekularne i kliniczne dotyczące roli lipidów $w$ patogenezie łuszczycy i jej związków z chorobami ogólnoustrojowymi (ryc. 1).

\section{LIPIDY W NASKÓRKU}

Warstwa rogowa naskórka pełni funkcję bariery między środowiskiem zewnętrznym i organizmem 


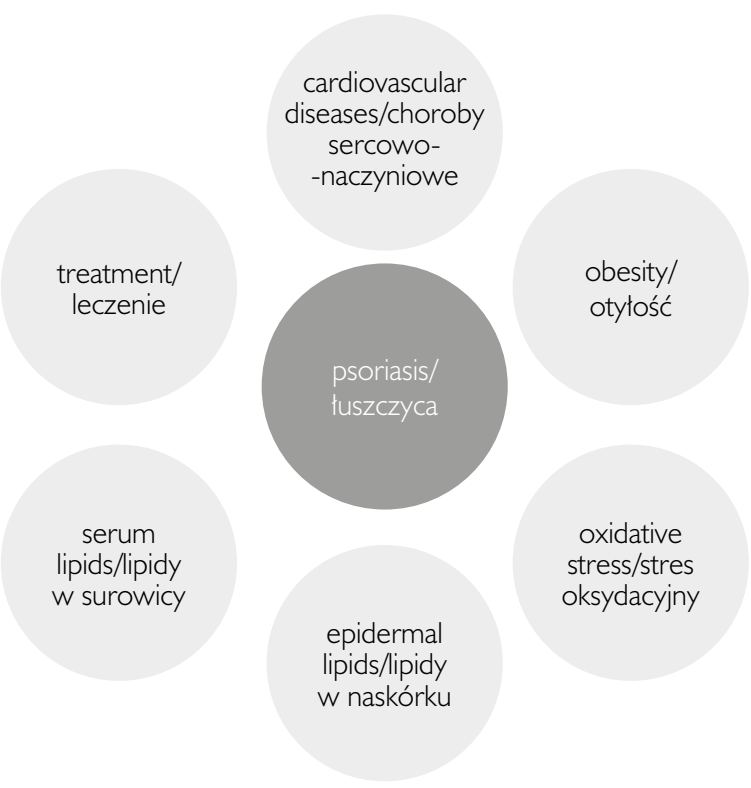

Figure I. Selected links between lipids and psoriasis

Rycina I. Wybrane aspekty powiq̨zań lipidów z łuszczyca

vents excessive transepidermal water loss (TEWL). Stratum corneum is composed of corneocytes surrounded by the extracellular matrix which is rich in lipids constituting $20 \%$ of the entire volume of stratum corneum. The main lipids in the epidermis are ceramides (CER) - 50\%, followed by cholesterol - $25 \%$ and free fatty acids (FFAs) - 15\%. Lipids are secreted from lamellar bodies found in keratinocytes through enzymatic transformations from phospholipids, glucosylceramides and sphingomyelin. The substances are then further metabolized to FFAs, ceramides and cholesterol in the intercellular matrix. They are arranged in the form of a compact spatial structure and together with corneocytes and protein envelopes create a brick-and-mortar-like pattern, thus providing a protective barrier $[9,10]$. Multiple studies investigating psoriasis have shown abnormalities in the stratum corneum structure itself, along with impairment in the function of enzymes involved in lipid metabolism, resulting in changes in their composition, and increased epidermal exfoliation and TEWL [10-14].

Among a multitude of theories formulated to account for the pathomechanism of psoriasis, one concept postulates a disturbance of cholesterol homeostasis. A high content of cholesterol has been found in skin scales shed in the process of psoriatic scaling. The skin of healthy individuals produces $85 \mathrm{mg}$ of cholesterol a day, however patients with psoriasis lose 1-2 $\mathrm{g}$ of cholesterol with skin scales over the same period $[9,15]$. Vaccaro et al. confirmed, both in vivo and in vitro, significant molecular and structural anomalies in the dermoepidermal junction in psoriatic lesions, potentially leading to abnormal keratino- oraz chroni przed nadmierną utratą wody (transepidermal water loss - TEWL). Jest zbudowana z korneocytów otoczonych przez zewnątrzkomórkową macierz bogatą w lipidy, które stanowią $20 \%$ objętości całej warstwy rogowej. Największą grupę lipidów w naskórku stanowią ceramidy (CER) - 50\%, następnie cholesterol - 25\% i wolne kwasy tłuszczowe (free fatty acids - FFAs) - 15\%. Lipidy są wydzielane z ciałek lamellarnych obecnych w keratynocytach poprzez przemiany enzymatyczne z fosfolipidów, glukozyloceramidów i sfingomieliny. Substancje te ulegają następnie w macierzy międzykomórkowej dalszemu metabolizmowi do FFAs, ceramidów i cholesterolu. Są ułożone w postaci przestrzennej, ścisłej struktury i wraz z korneocytami i kopertami białkowymi tworzą swoisty model "cegły i zaprawy", utrzymując $\mathrm{w}$ ten sposób barierę ochronną $[9,10]$. W wielu badaniach nad łuszczycą wykazano nieprawidłowości dotyczące struktury warstwy rogowej oraz upośledzonej funkcji enzymów biorących udział w metabolizmie lipidów, co skutkuje zaburzeniami w ich składzie, nasila złuszczanie naskórka oraz TEWL [10-14].

Istnieje wiele teorii dotyczących patomechanizmu łuszczycy, jedna z nich zakłada zaburzenie homeostazy cholesterolu. Stwierdzono, że dużą ilość tej substancji zawierają łuski, a pacjenci tracą ją wraz z ich złuszczaniem. Skóra osób zdrowych produkuje $85 \mathrm{mg}$ /dobę cholesterolu, natomiast chorzy na łuszczyce tracą w tym czasie 1-2 g cholesterolu wraz z łuskami $[9,15]$. Vaccaro i wsp. potwierdzili in vivo $\mathrm{i}$ in vitro istotne zaburzenia molekularne i strukturalne w połączeniu skórno-naskórkowym w zmianach łuszczycowych, które mogą prowadzić do nieprawidłowej adhezji keratynocytów, ich migracji i prolife- 
cyte adhesion, their migration and proliferation, and impairing the function of the basement membrane [11]. Psoriasis-related abnormalities are also seen in the stratum corneum, including expansion of the intercellular space, reduced cell adhesion or weakening of intercellular bonds [12]. Khyshiktuyev et al. noted increased levels of total lipids and individual lipid classes - phospholipids, triglycerides and cholesterol, both in the serum and stratum corneum, in patients with psoriasis. The concentrations were particularly high during flare-ups [13]. Similarly, Fortinskaia et al. demonstrated a positive correlation between free and total cholesterol levels in the epidermis and the severity of psoriasis [14].

Free fatty acids are involved not only in the process of energy accumulation or creation of cellular membranes, but they also have signalling roles in inflammatory and metabolic processes. Significantly reduced concentrations of short-chain fatty acids and monohydroxy fatty acids have been observed in the skin of psoriasis patients $[16,17]$.

Fatty acids contained in the stratum corneum are converted to their long-chain forms which are harmful in excess. They are bound by fatty acid binding proteins (FABPs) and transported to different tissues, where they are used. They were first identified in 1972 and since then a total of 9 isoforms have been found [18]. They play a role in the pathogenesis of metabolic diseases. In addition, they have found applications in the diagnostics of various diseases. Epidermal fatty acid binding protein (epidermal-FABP - E-FABP, FABP5) is present primarily in epidermal cells, but it can also be found in the brain, liver, lungs and adipose tissue. It plays an important role in maintaining the epidermal barrier and keratinocyte differentiation, but it is also involved in regulating insulin sensitivity and lipid homeostasis. E-FABP is also known as psoriasis-associated FABP (PA-FABP), which reflects its proven link to this dermatosis. A significantly increased expression of E-FABP has been demonstrated in psoriatic lesions $[19,20]$. The concentration of this protein in skin specimens failed to correlate with Psoriasis Area and Severity Index (PASI), however it exhibited a correlation with the severity of erythema, infiltration and scaling evaluated as PASI components [19]. Miyake et al. also assessed E-FABP during anti-TNF- $\alpha$ (tumour necrosis factor $\alpha$ ) and NB-UVB (narrow-band ultraviolet B) therapies. They found a decrease in the concentration of the protein under study after treatment and suggested that FABP-5 could be used as a marker for monitoring the efficacy of treatment. The study group, however, was very small - just 7 patients ( 2 treated with adalimumab, 3 with infliximab, 2 with NB-UVB), which is why the findings and conclusions of the study must be viewed as rather hypothetical [20]. racji oraz upośledzać funkcję błony podstawnej [11]. W warstwie rogowej w przebiegu łuszczycy również obserwuje się nieprawidłowości, takie jak poszerzone przestrzenie międzykomórkowe, zmniejszona adhezja komórek, mniej trwałe połączenia międzykomórkowe [12]. Khyshiktuyev i wsp. stwierdzili zwiększone stężenia lipidów ogółem oraz poszczególnych składowych - fosfolipidów, trójglicerydów i cholesterolu, zarówno w surowicy, jak i w warstwie rogowej pacjentów z łuszczycą. Były one szczególnie duże w momencie zaostrzeń choroby [13]. Podobnie Fortinskaia i wsp. wykazali dodatnią korelację między stężeniem cholesterolu wolnego i całkowitego w naskórku a ciężkością łuszczycy [14].

Wolne kwasy tłuszczowe biorą udział nie tylko $\mathrm{w}$ gromadzeniu energii czy tworzeniu błon komórkowych, lecz także odgrywają role sygnałowe w procesach zapalnych i metabolicznych. W skórze pacjentów z łuszczycą wykazano znamiennie zmniejszone stężenie krótkołańcuchowych kwasów tłuszczowych oraz monohydroksykwasów tłuszczowych [16, 17].

Kwasy tłuszczowe zawarte w warstwie rogowej naskórka są przekształcane do form długołańcuchowych, których nadmiar jest szkodliwy. Są one wiązane przez białka wiążące kwasy tłuszczowe (fatty acid binding proteins - FABPs), transportowane do różnych tkanek i utylizowane. Zostały one zidentyfikowane w 1972 r. i do tej pory poznano ich 9 izoform [18]. Odgrywają one rolę w patogenezie chorób metabolicznych, znalazły zastosowanie w diagnostyce różnych schorzeń. Naskórkowe białko wiążące kwasy tłuszczowe (epidermal-FABP - E-FABP, FABP5) występuje głównie w komórkach naskórka, a także w mózgu, wątrobie, płucach i tkance tłuszczowej. Bierze udział w utrzymaniu bariery naskórkowej, różnicowaniu keratynocytów, w regulacji insulinowrażliwości i homeostazy lipidów. E-FABP jest nazywane również białkiem związanym z łuszczycą (psoriasis-associated FABP - PA-FABP), co podkreśla już udowodnione powiązania $\mathrm{z}$ tą dermatozą. Wykazano istotnie zwiększoną ekspresję E-FABP w zmianach łuszczycowych $[19,20]$. Stężenie tego białka w wycinkach skórnych nie korelowało z PASI (Psoriasis Area and Severity Index), natomiast korelowało $\mathrm{z}$ nasileniem rumienia, nacieku i łuski, ocenianych jako składowe skali PASI [19]. Miyake i wsp. badali również E-FABP $w$ trakcie terapii anty-TNF- $\alpha$ (tumor necrosis factor $\alpha$, czynnik martwicy guza) i NB-UVB (narrow-band ultraviolet $B$, fototerapia wąskim spektrum UVB). Stwierdzili zmniejszone stężenia badanego białka po leczeniu i sugerowali, że FABP-5 może być markerem służącym do monitorowania efektywności terapii. Grupa badana była jednak bardzo nieliczna - 7 pacjentów (2 leczonych adalimumabem, 3 infliksymabem, 2 NB-UVB), co powoduje, że wyniki i wnioski są raczej hipotetyczne [20]. 
Sphingolipids are a group of lipids which have a very important role as a component of the epidermal layer. They regulate the biological functions of keratinocytes and inflammatory cells in the skin. The most active sphingolipids include ceramides, sphingomyelin, sphingosine-1-phosphate (S1P) and glycosphingolipids. Ceramides are involved in processes of proliferation, differentiation and apoptosis of keratinocytes. They are associated with ischaemic heart disease, insulin resistance, MS, obesity and formation of atheromatous plaque [21, 22]. S1P is an antagonist of ceramides, regulating immune response and angiogenesis [21, 22]. A reduced amount of CER in psoriatic skin, compared to unaffected skin, and an increased amount of sphingosine, a precursor of S1P, have been demonstrated [23, 24]. Mice deficient in serine palmitoyltransferase (SPT) enzyme involved in CER synthesis, have been found to develop histopathologically verified psoriasis-like lesions [25]. Furthermore, studies have revealed a reduction in de novo synthesis of ceramides (4.3-78.8\%), a decreased activity of enzymes (SPT and sphingomyelinase) and a reduced amount of CER in biopsies of psoriatic lesions, compared to unaffected skin. The values had a positive correlation with PASI $[23,26]$. Checa et al. reported slightly different findings. The concentration of CER was elevated in psoriatic skin, compared to unchanged skin and healthy individuals, however only in patients with a severe form of the disease [27]. Abnormalities are noted not only in the amount but also in the composition of ceramides. Motta et al. noted a significantly reduced amount of class-1 ceramides containing long-chain fatty acids in psoriatic plaques in comparison to the stratum corneum of healthy individuals, which was attributed to an increase in TEWL [12]. Also, psoriatic lesions were found to contain less prosaposin, a protein involved in the hydrolysis of sphingolipids, leading to a decreased amount of CER [28].

\section{SERUM LIPIDS}

\section{Cholesterols, triglycerides and apolipoproteins}

There are a number of studies demonstrating various abnormalities in the lipid profile in patients with psoriasis. Most research has shown a significant increase in cholesterol, low density lipoproteins (LDL) and triglycerides (TG), and a drop in high density lipoproteins (HDL) in the serum of patients with psoriasis [29-33]. Study findings related to the lipid profile are frequently inconsistent, sometimes even contradictory, which may be due to genetic factors, severity of the disease, drugs used by the patient, lifestyle or dietary habits $[10,29,34]$. Similarly, there is no consistency in data on the relationship between lipids and the sever-
Sfingolipidy są grupą lipidów stanowiących ważny element bariery naskórkowej. Regulują funkcje biologiczne keratynocytów i komórek zapalnych w skórze. Najbardziej aktywne to: ceramidy, sfingomielina, sfingozyno-1-fosforan (sphingosine-1-phosphate - S1P) i glikosfingolipidy. Ceramidy biorą udział w procesach proliferacji, różnicowania i apoptozy keratynocytów. Wiążą się z chorobą niedokrwienną serca, insulinoopornością, MS, otyłością oraz tworzeniem blaszki miażdżycowej [21, 22]. Z kolei S1P jest antagonistą ceramidów, reguluje odpowiedź immunologiczną i angiogenezę [21, 22]. Wykazano zmniejszoną ilość CER w skórze zmienionej łuszczycowo $\mathrm{w}$ porównaniu z niezajętą chorobą oraz zwiększoną ilość sfingozyny, prekursora S1P [23, 24]. U myszy pozbawionych enzymu palmitoilotransferazy serynowej (serine palmitoyltransferase - SPT), biorącego udział w syntezie CER, wystąpiły zmiany łuszczycopodobne potwierdzone histopatologicznie [25]. Stwierdzono ponadto zmniejszoną syntezę ceramidów de novo (4,3-78,8\%), mniejszą aktywność enzymów (SPT i sfingomielinazy) oraz zmniejszoną ilość CER w wycinkach zmian łuszczycowych $w$ porównaniu ze skórą niezmienioną, a wartości te pozytywnie korelowały z PASI [23, 26]. Checa i wsp. uzyskali nieco odmienne wyniki - stężenie CER było zwiększone w skórze łuszczycowej w porównaniu z niezmienioną i osób zdrowych, ale tylko u chorych z ciężką postacią łuszczycy [27]. Zaburzona jest nie tylko ilość, lecz także skład ceramidów. Motta i wsp. wykazali znamiennie zmniejszoną ilość ceramidów klasy 1 , zawierających długołańcuchowe kwasy tłuszczowe, w blaszkach łuszczycowych w porównaniu $\mathrm{z}$ warstwą rogową osób zdrowych, co było związane ze wzrostem TEWL [12]. Stwierdzono również mniejszą ilość prosapozyny w zmianach łuszczycowych, białka biorącego udział w hydrolizie sfingolipidów, co prowadzi do obniżenia ilości CER [28].

\section{LIPIDY W SUROWICY}

\section{Cholesterole, trójglicerydy i apolipoproteiny}

Przeprowadzono wiele badań, w których stwierdzono różne odchylenia w lipidogramie pacjentów z łuszczycą. W większości z nich wykazano istotny wzrost stężenia cholesterolu, lipoprotein o małej gęstości (low density lipoprotein - LDL) i trójglicerydów (triglycerides - TG) oraz redukcję stężenia lipoprotein o dużej gęstości (high density lipoprotein - HDL) w surowicy chorych na łuszczycę [29-33]. Wyniki badań dotyczących profilu lipidowego są często niespójne, a nawet przeciwstawne, co może być wynikiem czynników genetycznych, ciężkości choroby, przyjmowanych leków, stylu życia i diety [10, 29, 34]. Różne są też dane dotyczące korelacji lipidów z ciężkością 
ity of psoriasis, however the correlation is frequently described as positive [29,34]. Interesting findings were reported in the study by Veetil et al., who observed a paradoxical decrease in cholesterol, LDL and HDL, and an increase in TG, 5 years before the development of initial psoriatic lesions, and progressively atherogenic lipid profile in the course of the disease [32].

Apolipoproteins are the protein components of lipoproteins which are essential to normal lipid metabolism and linked to the development of CVD. The available study results are, again, inconsistent. Many authors have shown elevated concentrations of apolipoproteins (apo A1, apo B, apo C and apo E) in the serum of patients with psoriasis [35-37]. Some studies have found no change relative to the control group [38, 39], and others have shown a decrease in apolipoprotein levels [34].

It is also worthwhile to report data on the recently proposed lipid tetrad index (LTI). It is a specific formula which consists of a product of cholesterol, TG and lipoprotein(a) (Lp[a]) values in the numerator and the value of HDL in the denominator. Sunitha et al. showed that LTI was a stronger predictor of ischaemic heart disease compared to other classical risk factors and lipid parameters in patients with psoriasis, and it correlated with the activity of the disease [40].

\section{Phospholipids}

Data on the concentration of phospholipids in the serum of psoriatic patients vary considerably, however it also needs to be noted that phospholipids are a very complex group of lipids. A number of studies have shown a decrease in the total concentration of phospholipids, phosphatidylethanolamine, lecithin, linolenic acid, and docosatetraenoic and docosapentaenoic acids $[9,41]$. Some studies demonstrate an increase in some fractions, such as palmitic acid and palmitooleic acid, while others show no differences $[9,27,42]$. An increase in CER, both in skin lesions and in the serum of patients with psoriasis, has been shown, however only in association with the severe course of the disease. The findings point to a relationship between metabolism and lipid composition in the epidermis and serum [27]. In another study, the total concentration of CER was significantly reduced in patients with psoriasis, with differences also noted in individual CER fractions, and S1P was significantly higher than in the control group. The values of CER and S1P did not correlate with PASI or with inflammatory or metabolic markers. Interestingly, the CER values were higher in patients with psoriatic arthritis than in patients without articular involvement. It is conceivable that in the future an assessment of ceramide concentration will serve as a predictive factor for joint involvement in patients with psoriasis [21]. The hypothesis is evi- łuszczycy, często jednak jest ona pozytywna [29, 34]. Ciekawe wyniki uzyskali Veetil i wsp., którzy stwierdzili 5 lat przed rozwojem pierwszych zmian łuszczycowych paradoksalną redukcję stężenia cholesterolu, LDL i HDL oraz wzrost TG, a także postępujący aterogenny profil lipidowy w trakcie choroby [32].

Apolipoproteiny to białkowe części lipoprotein, niezbędne w prawidłowym metabolizmie lipidów i związane z rozwojem CVD. Wyniki badań są również niespójne. Wielu autorów wykazało zwiększone stężenie apolipoprotein (apo A1, apo B, apo C i apo E) w surowicy chorych na łuszczycę [35-37]. Niektórzy nie obserwowali zmian w porównaniu z grupą kontrolną [38, 39], inni stwierdzili zmniejszenie ich stężenia [34].

Warto wspomnieć o niedawno zaproponowanym indeksie lipidowym - lipid tetrad index. Oblicza się go według wzoru, w którym w liczniku znajduje się iloczyn wartości cholesterolu, TG i lipoproteiny (a) [Lp(a)], a w mianowniku - HDL. Sunitha i wsp. wykazali, że jest to silniejszy wskaźnik predykcyjny choroby niedokrwiennej serca w porównaniu z innymi klasycznymi czynnikami ryzyka i parametrami lipidowymi u pacjentów z łuszczycą, który koreluje $\mathrm{z}$ aktywnością choroby [40].

\section{Fosfolipidy}

Różne są dane dotyczące stężenia fosfolipidów w surowicy chorych na łuszczycę. Należy też pamiętać, że jest to bardzo szeroka grupa lipidów. $\mathrm{W}$ wielu badaniach stwierdzono zmniejszenie całkowitego stężenia fosfolipidów, fosfatydyloetanolaminy, lecytyny, kwasu linolenowego, kwasu dokozatetraenowego, dokozapentaenowego [9, 41]. W niektórych pracach odnotowano wzrost pewnych frakcji, np. kwasu palmitynowego, palmitooleinowego, w innych nie było różnic [9, 27, 42]. Wykazano wzrost CER zarówno w zmianach skórnych, jak i w surowicy pacjentów z łuszczycą, ale wyłącznie w przypadkach o ciężkim przebiegu. Wskazuje to na związek między metabolizmem a składem lipidów w naskórku oraz w surowicy [27]. W innym badaniu całkowite stężenie CER było znamiennie zmniejszone u pacjentów z łuszczycą, poszczególne frakcje również się różniły, a S1P było znacząco podwyższone w porównaniu z grupą kontrolną. Wartości CER i S1P nie korelowały z PASI czy wskaźnikami zapalnymi i metabolicznymi. Interesujące, że u pacjentów z łuszczycowym zapaleniem stawów stwierdzono wyższe wartości CER niż u pacjentów bez zajęcia stawów. Być może ocena stężeń ceramidów będzie mogła w przyszłości posłużyć jako czynnik przepowiadający zajęcie stawów u pacjentów z łuszczycą [21]. Tę hipotezę potwierdza fakt, że wykazano istotnie zwiększoną ilość CER w płynie maziowym $\mathrm{w}$ zmienionych zapalnie stawach $\mathrm{w}$ przebiegu reu- 
denced by the fact that a significant increase in the amount of CER has been noted in the synovial fluid of inflammation-affected joints secondary to rheumatoid arthritis [43]. It is also important to note that ceramides are associated with the formation of atheromatous plaque and may be one of the links connecting psoriasis with CVD and other metabolic diseases, similarly to S1P, which has a predictive value for coronary artery stenosis [21]. Attention should also be given to ponesimod, an orally used selective reversible modulator of the S1P receptor (S1R1), which is currently in the trial phase. It is involved in the metabolism of sphingolipids and reduces the amount of circulating lymphocytes. Preliminary data suggest the efficacy and safety of ponesimod in patients with psoriasis. It is difficult to assess the efficacy of the drug precisely, however it appears to be comparable to etanercept and higher than methotrexate [22].

\section{Fatty acids}

Free fatty acids induce pro- or antiinflammatory effects depending on the chain length and saturation. The supply of saturated fatty acids (SFA) is commonly known to increase the risk of CVD, and a diet rich in polyunsaturated fatty acids (PUFAs) and monounsaturated fatty acids (MUFAs) is associated with a lower rate of immunometabolic diseases [42]. The most recent study in patients with psoriasis has shown marked abnormalities in the FA profile. Even though the total FA concentration was similar to that in the control group, there were significant differences in individual acids. A significant rise in the $n-6 / n-3$ ratio and a reduction in omega-3 PUFAs were observed [42]. A positive correlation was identified between PASI and the ratio of $n-6 / n-3$ PUFAs, and a negative correlation was found between PASI and eicosapentaenoic acid (EPA) and docosahexaenoic acid (DHA), and n-3 PUFAs. Patients with psoriasis and coexisting metabolic diseases had significantly higher concentrations of FAs, SFA, MUFA and SFA/UFA. Also, significantly higher SFA and lower PUFA levels were found in men that in women. The SFA/UFA ratio increased along with the duration of the disease, which proves indirectly that the risk of developing metabolic disorders rises in proportion to the duration of psoriasis [42]. The importance of supplementation with omega-3 fatty acids in patients with psoriasis is discussed below.

\section{Fatty acid-binding proteins}

The recent literature contains only a few studies assessing the serum level of FABPs in patients with psoriasis. The majority of studies to date have investigated E-FABP. Miyake et al. failed to demonstrate a difference in FABP5 concentration between the matoidalnego zapalenia stawów [43]. Warto również podkreślić, że ceramidy wiążą się z tworzeniem blaszki miażdżycowej i mogą być jednym z ogniw łączących łuszczycę z CVD i innymi chorobami metabolicznymi, podobnie jak S1P, który ma wartość predykcyjną dla zwężenia tętnic wieńcowych [21]. Warto wspomnieć o doustnym leku ponesimod, który jest selektywnym, odwracalnym modulatorem receptora S1P (S1R1) w fazie badań. Bierze on udział w metabolizmie sfingolipidów i zmniejsza ilość krążących limfocytów. Wstępne dane sugerują skuteczność i bezpieczeństwo ponesimodu u chorych na łuszczycę. Trudno jednoznacznie ocenić skuteczność leku, ale wydaje się, że jest ona podobna do etanerceptu i większa od metotreksatu [22].

\section{Kwasy tłuszczowe}

Wolne kwasy tłuszczowe mają działanie pro- lub przeciwzapalne $\mathrm{w}$ zależności od długości i nasycenia. Powszechnie wiadomo, że podaż nasyconych kwasów tłuszczowych (saturated fatty acids - SFA) zwiększa ryzyko wystąpienia CVD, a dieta bogata w wielonienasycone kwasy tłuszczowe (polyunsaturated fatty acid - PUFAs) i w mononienasycone kwasy tłuszczowe (monounsaturated fatty acids - MUFAs) wiąże się z niższym odsetkiem chorób immunometabolicznych [42]. W najnowszym badaniu dotyczącym pacjentów z łuszczycą stwierdzono wyraźne odchylenia w profilu FA. Wprawdzie całkowite ich stężenie było podobne jak w grupie kontrolnej, jednak poszczególne rodzaje kwasów różniły się znacząco. Obserwowano znamienny wzrost wskaźnika n-6/n-3 oraz zmniejszone stężenie kwasów omega-3 PUFA [42]. Stwierdzono dodatnią korelację PASI ze wskaźnikiem n-6/n-3 PUFA, a ujemną ze stężeniem kwasu eikozapentaenowego (EPA), kwasu dokozaheksaenowego (DHA) i n-3 PUFA. U pacjentów z łuszczycą i współistniejącymi chorobami metabolicznymi występowały znacząco większe stężenia całkowite FAs, SFA, MUFA, SFA/UFA, u mężczyzn istotnie większe wartości SFA i mniejsze PUFA w porównaniu z kobietami. Wskaźnik SFA/UFA wzrastał z czasem trwania choroby, co pośrednio dowodzi, że ryzyko rozwoju zaburzeń metabolicznych zwiększa się z czasem trwania łuszczycy [42]. Istotną rolę suplementacji kwasami omega-3 w łuszczycy przedstawiono w dalszej części pracy.

\section{Białka wiążące kwasy tłuszczowe}

W aktualnym piśmiennictwie dostępne są pojedyncze badania oceniające FABPs w surowicy chorych na łuszczycę, większość dotyczyła E-FABP. Miyake i wsp. nie wykazali różnicy w stężeniach FABP5 między grupą badaną i kontrolną, mimo zwiększonej ekspresji w zmianach łuszczycowych [20]. 
study and control groups, despite an elevated expression in psoriatic lesions [20].

Heart-type fatty acid binding protein (heart-FABP - H-FABP, FABP-3), which is present in cardiomyocytes and skeletal muscles, is a highly sensitive marker of MI and a predictive factor for ischaemic heart disease in patients with MS. It is known to increase in diabetic patients [44]. In contrast, adipocyte fatty acid-binding protein (adipocyte-FABP - A-FABP, FABP-4), which is present in adipose tissue and macrophages, has a role in angiogenesis and atherosclerosis. Higher FABP-4 concentrations have been noted in non-alcoholic fatty liver disease (NAFLD), diabetes mellitus and obesity, which are psoriasis-associated metabolic diseases. A-FABP is also a predictor for CVD and MS [45]. The concentrations of other FABPs in the serum of psoriatic patients has so far been assessed in one study [46]. The mean concentration of A-FABP was significantly higher in patients with psoriasis, however there was no difference in H-FABP compared to the control group. No other significant correlations were found between FABPs and PASI, C-reactive protein (CRP), body mass index (BMI), glycaemia and lipid profile. The authors suggested that A-FABP could be a marker for psoriasis and a prognostic factor for comorbidities. The studies failed to confirm the tentative involvement of H-FABP in the assessment of CVD development in patients with psoriasis, however H-FABP may be linked to chronic inflammatory process and hepatic dysfunction in psoriatic patients [46].

\section{OXIDATIVE STRESS}

Chronic inflammation and various endogenous (e.g. chronic inflammatory process) and exogenous (e.g. smoking, imbalanced diet, alcohol) factors in psoriasis contribute to the formation of reactive oxygen species (ROS) and the superoxide anion, which leads to oxidative stress $[47,48]$. Disruption of the equilibrium between the amount of ROS and antioxidants causes lipid peroxidation and formation of oxidized-LDL (ox-LDL), consequently increasing the severity of atheromatosis and CVD. In addition, the production of eicosanoids with proinflammatory and chemotactic properties rises. In the course of psoriasis, during neutrophil penetration into the epidermis and formation of Munro's microabscesses, a large amount of ROS is produced, accompanied by oxidative damage to proteins and lipids, disorders of continuity of the epidermal barrier and further immunometabolic consequences. Multiple studies have shown that patients with psoriasis have elevated concentrations of peroxidation markers (including ox-LDL, autoantibodies against ox-LDL, malondialdehyde, homocysteine), and the abnormalities have
Sercowe białko wiążące kwasy tłuszczowe (heart-FABP - H-FABP, FABP-3), obecne w kardiomiocytach i mięśniach szkieletowych, jest niezwykle czułym wykładnikiem MI, czynnikiem predykcyjnym choroby niedokrwiennej serca u pacjentów z MS. Jego stężenie jest zwiększone $u$ chorych na cukrzycę [44]. Z kolei adipocytowe białko wiążące kwasy tłuszczowe (adipocyte-FABP - A-FABP, FABP-4), obecne w tkance tłuszczowej i makrofagach, odgrywa rolę $\mathrm{w}$ angiogenezie i miażdżycy. Większe stężenia FABP-4 stwierdzono w niealkoholowym stłuszczeniu wątroby (nonalcoholic fatty liver disease - NAFLD), cukrzycy, otyłości - chorobach metabolicznych związanych z łuszczycą. A-FABP jest także wskaźnikiem predykcyjnym CVD i MS [45]. Tylko w jednej pracy badano stężenia innych FABPs w surowicy osób z łuszczycą [46]. Średnie stężenie A-FABP było znamiennie większe u pacjentów z łuszczycą, a H-FABP nie różniło się w porównaniu z grupą kontrolną. Nie stwierdzono istotnych zależności między FABPs a PASI, białkiem C-reaktywnym (CRP), wskaźnikiem masy ciała (BMI), glikemią i lipidogramem. Autorzy sugerowali, że A-FABP może być markerem łuszczycy i czynnikiem prognostycznym schorzeń towarzyszących. Badania nie potwierdziły znaczenia H-FABP w ocenie ryzyka rozwoju CVD u chorych na łuszczycę, ale białko to może być związane z przewlekłym procesem zapalnym i zaburzeniami funkcji wątroby u tych pacjentów [46].

\section{STRES OKSYDACYJNY}

Przewlekły stan zapalny oraz różne czynniki endogenne (np. przewlekły proces zapalny) i egzogenne (m.in. palenie tytoniu, nieprawidłowa dieta, alkohol) u osób z łuszczycą wpływają na tworzenie wolnych rodników tlenowych (reactive oxygen species - ROS) i anionu ponadtlenkowego, co prowadzi do stresu oksydacyjnego [47, 48]. Zaburzenie równowagi między liczbą ROS a antyutleniaczami powoduje peroksydację lipidów i powstawanie utlenionej frakcji LDL (oxidized-LDL - ox-LDL), a także m.in. nasilenie miażdżycy i CVD. Zwiększa się również produkcja eikozanoidów o działaniu prozapalnym i chemotaktycznym. W łuszczycy, w trakcie przenikania neutrofilów do naskórka i tworzenia mikroropni Munro, dochodzi do produkcji dużej ilości ROS, uszkodzenia oksydacyjnego białek i lipidów, zaburzenia integralności bariery naskórkowej i dalszych konsekwencji immunometabolicznych. W wielu badaniach potwierdzono, że pacjenci z łuszczycą mają zwiększone stężenia markerów peroksydacji (m.in. ox-LDL, autoprzeciwciała przeciwko ox-LDL, dialdehyd malonowy, homocysteina), a zaburzenia te zwykle korelowały z aktywnością łuszczycy i czasem jej trwania [9, 47-49]. 
typically been correlated with the activity and duration of psoriasis [9, 47-49].

\section{PEROXISOME PROLIFERATOR-ACTIVATED RECEPTORS}

Peroxisome proliferator-activated receptors (PPARs) are another element connecting lipid metabolism disorders with immune processes. PPARs belong to the group of steroid nuclear receptors. They have been shown to occur in three isoforms: PPAR- $\alpha,-\beta$ and $-\gamma$. PPARs are activated by FA and their derivatives, and they regulate the metabolism of carbohydrates, lipids and proteins, and inhibit atherogenesis and proliferation of diverse cells including keratinocytes. PPAR- $\alpha$ affects the elimination of cholesterol by macrophages, and inhibits the synthesis of proinflammatory cytokines, similarly to PPAR- $\beta[9,50,51]$. Psoriasis is accompanied by a reduced expression of PPAR- $\alpha$ and $-\gamma$, and an increased expression of PPAR- $\beta$. Hegazy et al. noted a significant decrease in PPAR- $\gamma$ in psoriatic patients, compared to healthy individuals. It was particularly low in the subgroups of patients with diabetes and arterial hypertension, and the lowest in patients with psoriasis and MS. The authors found a positive correlation between PPAR- $\gamma$ and HDL, and a negative correlation with PASI, BMI and glycaemia [51]. On account of their role in regulating the homeostasis of lipids and the inflammatory state, PPARs and their ligands have attracted interest as a potential therapeutic option. An improvement in psoriatic lesions has been observed in diabetic patients treated with oral troglitazone and pioglitazone (PPAR- $\gamma$ agonists) $[52,53]$. However, the efficacy of PPAR agonists used topically in psoriasis has not been demonstrated [50].

\section{COMORBIDITIES OF PSORIASIS}

\section{Cardiovascular diseases}

Multiple studies have demonstrated a significant link between psoriasis and proatherogenic lipid profile as well as other risk factors leading to cardiovascular diseases [31, 37, 40,48,54-56]. Sunitha et al. showed significantly higher levels of oxidative stress indices, atherogenic index, lipid tetrad index and dyslipidaemia, which correlated positively with the severity of psoriasis and indicated an increased risk of CVD [40]. Other factors contributing to lipid disorders and the development of atherosclerosis include chronic inflammation and proinflammatory cytokines (e.g. TNF- $\alpha$, interleukin-1 and -6) which play an important role in the pathogenesis of psoriasis and, at the same time, result in an increase in TG and FA synthesis [57]. The risk of CVD and arterial hypertension in psoriasis patients is, respectively, four and two-three

\section{RECEPTORY AKTYWOWANE PRZEZ PROLIFERATORY PEROKSYSOMÓW}

Receptory aktywowane przez proliferatory peroksysomów (peroxisome proliferator activated receptors - PPARs) są kolejnym elementem łączącym zaburzenia metabolizmu lipidów i procesy immunologiczne. Należą do grupy steroidowych receptorów jądrowych. Zidentyfikowano ich trzy izoformy: PPAR- $\alpha,-\beta$ i - $\gamma$. Są one aktywowane przez FA i ich pochodne, regulują metabolizm węglowodanów, tłuszczów i białek, hamują aterogenezę oraz proliferację różnych komórek, w tym keratynocytów. PPAR- $\alpha$ wpływa na usuwanie cholesterolu przez makrofagi, hamuje syntezę cytokin prozapalnych, podobnie PPAR- $\beta[9,50,51]$. W łuszczycy ekspresja PPAR- $\alpha$ i $-\gamma$ jest zmniejszona, a PPAR- $\beta$ wzrasta. Hegazy i wsp. stwierdzili istotne zmniejszenie poziomu PPAR- $\gamma$ u pacjentów z łuszczycą $\mathrm{w}$ porównaniu z osobami zdrowymi, który był szczególnie mały w podgrupach z cukrzycą, nadciśnieniem tętniczym, a najmniejszy u chorych z łuszczycą i MS. Autorzy wykazali pozytywną korelację PPAR- $\gamma$ z HDL, a negatywną z PASI, BMI i glikemią [51]. Ze względu na rolę $\mathrm{w}$ regulacji homeostazy lipidów i stanu zapalnego PPARs i ich ligandy wzbudziły zainteresowanie jako potencjalna opcja terapeutyczna. Obserwowano poprawę zmian łuszczycowych u pacjentów z cukrzycą leczonych doustnie troglitazonem i pioglitazonem (agoniści PPAR- $\gamma$ ) [52, 53]. Nie wykazano jednak skuteczności agonistów PPAR stosowanych miejscowo w łuszczycy [50].

\section{CHOROBY WSPÓŁISTNIEJACE Z ŁUSZCZYCA}

\section{Choroby sercowo-naczyniowe}

W wielu badaniach potwierdzono, że łuszczyca jest istotnie związana $\mathrm{z}$ proaterogennym profilem lipidowym oraz innymi czynnikami ryzyka wystąpienia chorób sercowo-naczyniowych [31, 37, 40, 48, 54-56]. Sunitha i wsp. wykazali znamiennie wyższe wartości wskaźników stresu oksydacyjnego, indeksu aterogennego, lipid tetrad index i dyslipidemii, które pozytywnie korelowały z ciężkością łuszczycy i wskazywały na zwiększone ryzyko wystąpienia CVD [40]. Na zaburzenia lipidowe i rozwój miażdżycy wpływają przewlekły proces zapalny oraz cytokiny prozapalne (m.in. TNF- $\alpha$, interleukiny 1 i 6), istotne w patogenezie łuszczycy, a jednocześnie prowadzące do wzrostu TG i syntezy FA [57]. Ryzyko wystąpienia CVD jest 4-krotnie wyższe, a nadciśnienia tętniczego - 2-3-krotnie wyższe u chorych na łuszczycę niż w populacji ogólnej. Łuszczyca jest niezależnym czynnikiem ryzyka wystąpienia MI, zwłaszcza u osób młodych z ciężką postacią choroby. 
times higher than in the general population. Psoriasis is an independent risk factor for MI, particularly in young patients with a severe form of the disease. Dyslipidaemia is correlated with an increased mortality from MI and stroke [58]. Epicardial fat tissue (EFT) plays an important role in CVD development via proinflammatory cytokines and adipokines which are synthesized in that tissue. A meta-analysis conducted by Wang et al. confirmed a significantly increased amount of EFT in patients with psoriasis and its relevance as an element linking the dermatosis to CVD [59].

Argote et al. assessed the incidence of cardiovascular risk factors in 40 patients with psoriasis. Hypertension occurred in 35\% of the patients and dyslipidaemia in $17.5 \%$. A positive history of smoking was noted in $17.5 \%$ of the subjects, and $10 \%$ had type 2 diabetes mellitus. Based on the Framingham Coronary Heart Disease Risk Score, the risk of CVD was low in $31.4 \%$ of the subjects, moderate in $62.8 \%$ and high in $5.7 \%$ of the study patients [60].

\section{Obesity}

The associations between obesity and psoriasis are multifaceted and indisputable. Obesity is known to be a factor predisposing to psoriasis, and psoriasis is a factor increasing the risk of obesity. Possible explanations include a common genetic background or chronic inflammation underlying the psoriatic march which leads to the development of atheromatosis [5]. The relationship between psoriasis and obesity is also influenced by socioeconomic and environmental factors, and in addition by a range of bioactive substances produced by the adipose tissue, including cytokines, growth factors, hormones or adipokines. The latter take part in maintaining systemic homeostasis, regulation of carbohydrate and lipid metabolism, haemostasis, insulin resistance, atherosclerosis, and inflammatory and immune processes. Numerous studies demonstrated the role of various adipokines in the pathogenesis of psoriasis in association with systemic diseases [61-64].

Excessive body weight is a risk factor for psoriasis and exhibits a correlation with the severity of psoriatic disease. The risk of obesity in patients with psoriasis is over twice as high as in the general population. On the other hand, obesity precedes the formation of psoriatic lesions, and the $\mathrm{BMI}$ is correlated with the risk of developing this dermatosis [5, 61]. The relationship between obesity and psoriasis is also evidenced by positive outcomes of bariatric surgery procedures in obese patients with psoriasis. An improvement or disease remission is noted in $40-60 \%$ of patients, based on recognized scores used for measuring the activity of psoriasis. Consequently, it is possible to reduce the dosage of systemic therapy used thus far or terminate treatment altogether in over $20 \%$ of patients $[65,66]$.
Dyslipidemia koreluje ze zwiększoną śmiertelnością z powodu MI i udaru [58]. Osierdziowa tkanka tłuszczowa (epicardial fat tissue - EFT) odgrywa ważną rolę w rozwoju CVD poprzez syntetyzowane w niej cytokiny prozapalne i adipokiny. Wang i wsp. przeprowadzili metaanalizę, która potwierdziła znamiennie zwiększoną ilość EFT u pacjentów z łuszczycą i jej znaczenie jako elementu łączącego tę dermatozę z CVD [59].

Argote i wsp. badali częstość występowania czynników ryzyka rozwoju CVD u 40 pacjentów z łuszczycą. Nadciśnienie tętnicze występowało u 35\% pacjentów, dyslipidemia u 17,5\%, dodatni wywiad palenia tytoniu u 17,5\%, cukrzyca typu 2 u $10 \%$ badanych. Ryzyko wystąpienia CVD ocenione na podstawie skali Framingham było niskie u 31,4\% badanych, średnie u 62,8\% i wysokie u 5,7\% [60].

\section{Otyłość}

Powiązania otyłości z łuszczycą są wielokierunkowe i niezaprzeczalne. Zarówno otyłość sprzyja wystąpieniu łuszczycy, jak i łuszczyca zwiększa ryzyko wystąpienia otyłości. Rozważa się wspólne podłoże genetyczne lub przewlekły stan zapalny, który leży u podstaw marszu łuszczycowego prowadzącego do rozwoju miażdżycy [5]. Na związek łuszczycy z otyłością mają wpływ czynniki socjoekonomiczne i środowiskowe, a także liczne bioaktywne substancje wydzielane przez tkankę tłuszczową, takie jak cytokiny, czynniki wzrostu, hormony, adipokiny. Te ostatnie biorą udział w utrzymaniu homeostazy organizmu, regulacji metabolizmu węglowodanów i tłuszczów, hemostazy, rozwoju insulinooporności, miażdżycy oraz procesów zapalnych i immunologicznych. W licznych badaniach udowodniono rolę różnych adipokin w patogenezie łuszczycy w powiązaniu z chorobami ogólnoustrojowymi [61-64].

Nadmierna masa ciała jest czynnikiem ryzyka wystąpienia łuszczycy i koreluje z jej ciężkością. Pacjenci z łuszczycą mają ponad 2-krotnie zwiększone ryzyko rozwoju otyłości. Otyłość często jednak wyprzedza pojawienie się zmian łuszczycowych, a BMI koreluje z ryzykiem wystąpienia tej dermatozy [5, 61]. Kolejnym potwierdzeniem związku otyłości z łuszczycą jest pozytywny wpływ operacji bariatrycznych $\mathrm{u}$ otyłych osób z tą dermatozą. Obserwuje się poprawę lub remisję u 40-60\% pacjentów, stwierdzone na podstawie uznanych skal oceny aktywności łuszczycy. Ponadto możliwe jest zmniejszenie dawkowania dotychczas stosowanej terapii ogólnej lub jej całkowite zakończenie u ponad $20 \%$ pacjentów $[65,66]$. Jest to wynikiem m.in. utraty masy ciała, zwiększonego wydzielania peptydu glukagonopodobnego 1, zmniejszenia motoryki przewodu pokarmowego i efektu przeciwzapalnego $[5,65,66]$. 
The above outcomes result from the body weight loss itself, but also from an increased production of glucagon-like peptide-1, reduced gastrointestinal motility and antiinflammatory effect $[5,65,66]$.

\section{Metabolic syndrome}

Metabolic syndrome affects $15-24 \%$ of the general population and $40-60 \%$ of psoriasis patients. Abdominal obesity and dyslipidaemia are the most significant factors leading to an increased incidence of MS in patients with this dermatosis. In addition, a link has been found between an increased frequency of metabolic syndrome components and the severity and duration of psoriasis [5, 67-70].

The risk of diabetes in patients with psoriasis is twice as high as in the general population. In addition, diabetic patients are at an elevated risk of developing psoriasis. The associations between obesity and diabetes are attributed, among others, to the common genetic background including micro-RNA molecules, environmental factors, chronic inflammatory process and excessive synthesis of adipokines and cytokines including the IL-23/IL-17 and IL-18 axes [70, 71].

\section{PSORIASIS TREATMENT AND LIPID DISORDERS}

The treatment of patients with psoriasis may be challenging, especially in cases with coexisting metabolic diseases. Obesity entails a lower efficacy of both topical and systemic therapies, including biological treatment [72]. On account of the relationship between obesity and other disorders, such as MS or NAFLD, there is an increased risk of adverse effects induced by drugs and loss of therapeutic response $[72,73]$. In methotrexate-treated patients with psoriasis obesity was shown to be a greater risk factor for hepatotoxicity than alcohol, viral hepatitis or cumulative drug dose [74]. Obese patients with psoriasis treated with cyclosporin A are at an increased risk of nephrotoxicity, which is why the dose of the drug should be adjusted based on the patient's ideal rather than the actual body weight [72]. The loss of body weight in psoriatic patients, in turn, contributes to an improved efficacy of therapy with cyclosporin A [72].

Irrespective of coexisting metabolic diseases, treatment used in psoriasis can also be a cause of lipid disorders predisposing to CVD. Cignoline stimulates oxidative stress by enhancing the peroxidation of lipids in keratinocytes and nucleated cells in peripheral blood [75]. Coimbra et al. demonstrated no effect of NB-UVB on the inflammatory process or decrease in the risk of atherogenicity: the levels of ox-LDL/LDL, Chol/HDL, CRP and Lp(a) still remained higher than in the control group. However, PUVA was found to induce a significant decrease in $\mathrm{Lp}(\mathrm{a})$ accompanied

\section{Zespół metaboliczny}

Zespół metaboliczny dotyczy 15-24\% populacji ogólnej i 40-60\% chorych na łuszczycę. Otyłość brzuszna i dyslipidemia to najbardziej istotne czynniki zwiększające częstość występowania MS u osób $\mathrm{z}$ tą dermatozą. Potwierdzono również częstsze pojawianie się składowych MS wraz ze wzrostem ciężkości i czasu trwania łuszczycy [5, 67-70].

Ryzyko wystąpienia cukrzycy u osób z łuszczycą jest dwukrotnie wyższe, a u pacjentów z cukrzycą stwierdza się zwiększone ryzyko rozwoju łuszczycy. Powiązania łuszczycy z otyłością i cukrzycą tłumaczy się m.in. wspólnym podłożem genetycznym, w tym cząsteczkami mikro-RNA, czynnikami środowiskowymi, przewlekłym procesem zapalnym i nadmierną syntezą adipokin i cytokin, m.in. osi IL-23/IL-17 oraz IL-18 [70, 71].

\section{LECZENIE ŁUSZCZYCY A ZABURZENIA LIPIDOWE}

Terapia pacjentów z łuszczycą może powodować trudności przy współistnieniu chorób metabolicznych. Otyłość wiąże się z mniejszą skutecznością leczenia, nie tylko miejscowego, lecz także ogólnego, w tym biologicznego [72]. Ze względu na związek otyłości z innymi zaburzeniami, takimi jak MS czy NAFLD, zwiększa się ryzyko wystąpienia działań niepożądanych leków, a także utraty odpowiedzi na leczenie $[72,73]$. U pacjentów z łuszczycą leczonych metotreksatem wykazano, że otyłość była większym czynnikiem ryzyka hepatotoksyczności niż alkohol, wirusowe zapalenie wątroby czy dawka kumulacyjna leku [74]. U otyłych osób z łuszczycą przyjmujących cyklosporynę A występuje większe ryzyko nefrotoksyczności, dlatego też zaleca się ustalanie dawki leku wg idealnej masy ciała chorego, a nie aktualnej [72]. Z kolei utrata masy ciała u pacjentów z łuszczycą wpływa na poprawę skuteczności terapii cyklosporyną A [72].

Pomijając współistniejące choroby metaboliczne, leczenie stosowane w łuszczycy może być również przyczyną zaburzeń lipidowych sprzyjających CVD. Cygnolina stymuluje stres oksydacyjny poprzez nasilanie peroksydacji lipidów w keratynocytach i komórkach jednojądrzastych krwi obwodowej [75]. Coimbra i wsp. nie stwierdzili wpływu NB-UVB na proces zapalny i zmniejszenie ryzyka aterogenności - ox-LDL/LDL, cholesterol/HDL, CRP, Lp(a) były nadal większe niż w grupie kontrolnej. Po leczeniu PUVA autorzy stwierdzili istotne zmniejszenie wartości Lp(a) i wzrost apo B. Wydaje się, że wpływ terapii PUVA na lipidy jest odmienny niż UVB, być może $\mathrm{z}$ uwagi na interakcje psoralenu $\mathrm{z}$ lipidami w surowicy, a dokładniej Lp(a) [76]. Metotreksat poprzez 
by an increase in apo B. It seems that PUVA has a different effect on lipids than UVB, which may be due to interactions between psoralene and serum lipids or, more specifically, lipoprotein(a) [76]. By inhibiting systemic inflammation, methotrexate lowers the risk of CVD and MI, but increases the concentration of homocysteine, which is one of the risk factors for the two diseases $[9,72]$. Retinoids carry the greatest risk of hyperlipidaemia. They induce an increase in the concentration of cholesterol, TG and LDL, and a decrease in HDL, particularly in patients with psoriasis and coexisting diabetes, obesity or alcohol addiction $[9,72]$. Conversely, Corbetta et al. found that disorders of glucose and lipid metabolism during acitretin therapy were transient and independent of the BMI [76]. Cyclosporin A is a highly lipophilic drug. It binds to lipoproteins and has a lower effect on the lipid profile, however it may cause a rise in TG [9].

TNF- $\alpha$ inhibitors may induce an increase in TG, elevate the synthesis of leptin and thus stimulate the appetite and increase body weight. On the other hand, they increase the level of HDL and decrease the concentration of insulin. The literature data show that biological drugs produce cardioprotective effects and reduce the risk of metabolic diseases [77].

Much attention has been focused on the role of statins in the treatment of patients with psoriasis, not only in dyslipidaemia. Used in cases of hyperlipidaemia in psoriasis, statins reduce the concentrations of CRP, LDL, TNF- $\alpha$ and arterial stiffness, and markedly lower the risk of CVD, among other effects [9]. In their analysis, Ports et al. found that statins significantly corrected lipid abnormalities and decreased the risk of CVD in patients with psoriasis [78, 79]. There are, as yet, no studies showing indisputably that statins have a beneficial effect on the course of psoriasis.

\section{DIET IN PSORIASIS}

Among many risk factors, lifestyle and nutrition significantly affect the course and treatment of psoriasis. Several studies have found that psoriatic patients tend to eat more simple sugars, fats and n-6 PUFAs, and have a higher intake of calories. On the other hand, they eat less proteins, complex carbohydrates, MUFA, n-3 PUFAs and dietary fibre. Inappropriate eating habits have exhibited a correlation with obesity, more severe course of psoriasis and impairment in the quality of life [80-83]. In the most recent questionnaire-based study, Afifi et al. assessed the eating habits of patients with psoriasis. A comparison with the results of the NHANES study (2009-2010) found that the respondents consumed less sugars and dairy products, and more fruit and vegetables. The findings suggest that there is an increased interest among pso- hamowanie ogólnoustrojowego stanu zapalnego zmniejsza ryzyko wystąpienia CVD i MI, ale zwiększa stężenie homocysteiny - jednego z czynników ryzyka powyższych chorób $[9,72]$. Retinoidy powodują największe ryzyko wystąpienia hiperlipidemii, wzrost stężenia cholesterolu, TG, LDL i zmniejszenie stężenia HDL, zwłaszcza u chorych na łuszczycę z towarzyszącą cukrzycą, otyłością i uzależnieniem od alkoholu [9, 72]. Corbetta i wsp. stwierdzili jednak, że zaburzenia metabolizmu glukozy i lipidów w trakcie terapii acytretyną były przemijające i niezależne od wartości BMI [76]. Cyklosporyna A jest wysoce lipofilnym lekiem i wiąże się z lipoproteinami, ma mniejszy wpływ na lipidogram, może jednak powodować wzrost stężenia TG [9].

Inhibitory TNF- $\alpha$ mogą prowadzić do wzrostu stężenia TG, nasilać syntezę leptyny oraz pobudzać apetyt i zwiększenie masy ciała. Powodują jednak wzrost stężenia HDL i zmniejszenie stężenia insuliny. Dane z piśmiennictwa dowodzą, że leki biologiczne mają działanie kardioprotekcyjne oraz zmniejszają ryzyko rozwoju chorób metabolicznych [77].

Wiele uwagi poświęca się znaczeniu statyn w leczeniu pacjentów z łuszczycą, nie tylko w przypad$\mathrm{ku}$ dyslipidemii. Leki stosowane $\mathrm{w}$ hiperlipidemii w przebiegu łuszczycy m.in. redukują stężenie CRP, LDL, TNF- $\alpha$ oraz sztywność tętnic, a także istotnie zmniejszają ryzyko wystąpienia CVD [9]. Ports i wsp. stwierdzili na podstawie swojej analizy, że statyny istotnie poprawiły zaburzenia lipidowe oraz zredukowały ryzyko rozwoju CVD u chorych na łuszczycę $[78,79]$. Nie istnieją obecnie badania jednoznacznie potwierdzające korzystny wpływ statyn na przebieg łuszczycy.

\section{DIETA W ŁUSZCZYCY}

Spośród wielu czynników ryzyka styl życia i sposób odżywiania znacząco wpływają na przebieg łuszczycy i jej leczenie. W kilku badaniach potwierdzono, że pacjenci z łuszczycą spożywają większe ilości cukrów prostych, tłuszczów, n-6 PUFA i kalorii, a mniej białek, węglowodanów złożonych, MUFA, $n$-3 PUFA i błonnika. Nieprawidłowe nawyki żywieniowe korelowały z występowaniem otyłości, cięższym przebiegiem łuszczycy i obniżeniem jakości życia [80-83]. W najnowszym badaniu opartym na kwestionariuszu Afifi i wsp. oceniali zwyczaje żywieniowe osób z łuszczycą. Zauważono, porównując z wynikami badania NHANES z lat 2009-2010, że respondenci spożywali mniej cukrów, produktów mlecznych, a więcej owoców i warzyw. Wskazuje to na wzrost zainteresowania chorych na łuszczyce sposobem odżywiania i motywację do zmiany negatywnych nawyków żywieniowych [83]. Brakuje jednak obiektywnych badań i jednoznacznych zaleceń dotyczą- 
riatic patients in proper nutrition, and a motivation to change negative eating habits [83]. However, objective studies and clear dietary recommendations for psoriasis are lacking. The literature comprises a number of papers with various dietary recommendations.

A reduced severity of psoriatic lesions has been observed after introducing a low-energy diet (LED), and prolonged remission of psoriasis after methotrexate therapy combined with LED [84, 85]. A low-calorie diet is believed to reduce the synthesis of proinflammatory leukotriene B4 and the amount of ROS [81].

Also, a diet consisting of red vegetables (carrots, tomatoes) and fruit rich in $\beta$-carotene, flavonoids and vitamin $C$, as well as selenium supplementation, are claimed to have an antioxidant activity [81]. On the other hand, it needs to be noted that patients with psoriasis participating in the questionnaire-based study referred to above mentioned sugar, alcohol, tomatoes and dairy products as the most common nutritional factors exacerbating skin lesions [83].

There are data indicating a positive effect of the vegetarian diet on limiting inflammation and oxidative stress, and increasing the intake of PUFA [81, 82, 84].

There is no consensus on the usefulness of gluten-free diet (GFD) in psoriasis. Psoriasis and coeliac disease probably share a genetic background. Also, an increased intestinal permeability is observed in both diseases, and an effect of vitamin D deficiency. Individuals with coeliac disease (CD) have a higher incidence of psoriasis ( $\mathrm{OR}=1.72$ ), however patients with psoriasis are also at an increased risk of developing $C D(O R=2.2-2.73)$ and an elevated risk of positive serological results for this disease. It seems, however, that gluten-free diet may have a desirable effect on the activity of psoriasis, though it is to be expected mostly in AGA-positive (antigliadin antibodies) patients. After 3 months of GFD, a significant PASI reduction was noted in $73 \%$ of the total of 33 AGA-positive patients, and AGA values were decreased in $82 \%$ of patients from this group $[86,87]$.

Studies have demonstrated that up to $50 \%$ of patients report excessive alcohol consumption. A positive correlation is observed between alcohol consumption and the severity of psoriasis. Alcohol causes blood vessel dilation, facilitating the migration of inflammatory cells, and it elevates the concentration of arachidonic acid and exacerbates oxidative stress. In addition, alcohol contributes to an increased incidence of anxiety and depression, and a greater intake of saturated fats. It is also associated with a poorer response to treatment $[81,88]$.

Omega-3 polyunsaturated fatty acids, including EPA and DHA, must be supplied in the diet because they are naturally produced in the human body in cych żywienia w łuszczycy. W piśmiennictwie można odnaleźć liczne prace dotyczące różnych zaleceń dietetycznych.

Obserwowano zmniejszenie nasilenia zmian łuszczycowych po zastosowaniu diety niskoenergetycznej (low-energy diet - LED), wydłużenie remisji łuszczycy po leczeniu metotreksatem w połączeniu z LED [84, 85]. Uważa się, że dieta niskokaloryczna zmniejsza syntezę prozapalnego leukotrienu B4 oraz ilość ROS [81].

Z kolei dieta złożona z czerwonych warzyw (m.in. marchewki, pomidorów) i owoców, bogatych $\mathrm{w} \beta$-karoten, flawonoidy i witaminę $\mathrm{C}$, oraz suplementacja selenem mają działanie antyoksydacyjne [81]. Należy jednak zaznaczyć, że we wspomnianym badaniu kwestionariuszowym pacjenci z łuszczycą do najczęstszych czynników żywieniowych zaostrzających zmiany skórne zaliczyli m.in. cukier, alkohol, pomidory i przetwory mleczne [83].

Niektóre dane potwierdzają pozytywny wpływ diety wegetariańskiej na ograniczenie stanu zapalnego, stresu oksydacyjnego i zwiększenie podaży PUFA [81, 82, 84].

Różne są poglądy dotyczące stosowania diety bezglutenowej w łuszczycy (gluten-free diet - GFD). Łuszczyca i celiakia mają prawdopodobnie wspólne podłoże genetyczne. Obserwuje się również zwiększoną przepuszczalność jelit w obu schorzeniach i wpływ niedoboru witaminy D. Osoby z celiakią częściej chorują na łuszczycę (OR = 1,72), a także u pacjentów z łuszczycą występuje większe ryzyko rozwoju celiakii (OR = 2,2-2,73) oraz zwiększone ryzyko dodatnich wyników serologicznych w kierunku choroby trzewnej. Wydaje się, że dieta bezglutenowa może korzystnie wpływać na aktywność łuszczycy, jednak raczej u pacjentów AGA-dodatnich (antigliadin antibodies - przeciwciała przeciwko gliadynie). Po 3 miesiącach stosowania GFD u 73\% spośród 33 pacjentów AGA-dodatnich stwierdzono istotną redukcję PASI, a u 82\% osób z tej grupy zmniejszyły się wartości AGA $[86,87]$.

W badaniach stwierdzono, że nawet do $50 \%$ chorych podaje w wywiadzie nadmierną konsumpcję alkoholu. Wykazano dodatnią korelację spożycia alkoholu z nasileniem łuszczycy. Alkohol powoduje rozszerzenie naczyń, ułatwiając migrację komórek zapalnych, zwiększa stężenie kwasu arachidonowego, nasila stres oksydacyjny, wpływa na częstsze występowanie lęku i depresji, sprzyja większemu spożyciu tłuszczów nasyconych, zmniejsza odpowiedź na leczenie $[81,88]$.

Wielonienasycone kwasy tłuszczowe omega-3, m.in. EPA i DHA, muszą być dostarczane w diecie, ponieważ organizm człowieka wytwarza ich znikomą ilość. PUFA mają szerokie działanie: przeciwzapalne, przeciwmiażdżycowe, antyarytmiczne, 
very small amounts. PUFAs exert a broad spectrum of effects: antiinflammatory, antiatherogenic and antiarrhythmic. They improve the lipid profile and insulin sensitivity indices, and normalize blood pressure. The ratio of $n-3 / n-6$ PUFAs should be $1: 1.8$, however in highly developed countries the diet is generally dominated by omega- 6 fatty acids at a ratio of 15-20: $1[89,90]$.

Literature reports show a beneficial effect of supplementation with omega-3 fatty acids in patients with psoriasis. Omega-3 acids have been shown to inhibit the concentration of phospholipase A2 in psoriatic lesions, reduce the release of proinflammatory arachidonic acid from cellular membranes, stimulate PPAR receptors, and lower oxidative stress. An improvement in psoriatic lesions has been observed in patients eating oily fish (mackerel, sardines, salmon, herring) and fish oils (EPA, DHA) as well as corn oil ( $\alpha$-linolenic acid) $[81,82,89,91]$. Adil et al. observed a $50 \%$ reduction in the PASI score in nearly half of patients after 12 weeks of omega- 3 supplementation at a dose of $1.8 \mathrm{~g} /$ day [92]. However, not all data are consistent, for example in terms of reduction of individual PASI components or the efficacy of supplementation as such $[82,93]$.

\section{CONCLUSIONS}

Lipids play an indisputable role in the pathogenesis of psoriasis. They affect the links between psoriasis and systemic diseases and immune disorders. Comprehensive diagnostic measures are necessary to identify risk factors for CVD and, in particular, obesity and its metabolic effects in patients with psoriasis. Early therapeutic and educational activities are crucial in order to promote a health-oriented lifestyle. Similar importance should be attached to the pharmacological treatment of lipid and carbohydrate metabolism disorders. In addition, diet should not be overlooked as an important element in the prevention and comprehensive treatment of patients with psoriasis. poprawiają profil lipidowy i wskaźniki insulinowrażliwości oraz normalizują ciśnienie tętnicze. Stosunek PUFA $n$ - 3 do $n-6$ powinien wynosić 1 : 1,8, ale w krajach wysokorozwiniętych przeważają $\mathrm{w}$ diecie kwasy omega-6 w stosunku 15-20: 1 [89, 90].

Dane z piśmiennictwa dowodzą korzystnego wpływu suplementacji kwasami omega-3 na łuszczycę. Potwierdzono, że hamują one zwiększone stężenie fosfolipazy A2 w zmianach łuszczycowych, zmniejszają uwalnianie prozapalnego kwasu arachidonowego z błon komórkowych, pobudzają receptory PPAR, zmniejszają stres oksydacyjny. Obserwowano poprawę zmian łuszczycowych u osób spożywających tłuste ryby (makrela, sardynki, łosoś, śledzie), oleje rybne (EPA, DHA) i olej kukurydziany (kwas $\alpha$-linolenowy) $[81,82,89,91]$. W badaniu Adil i wsp. po 12 tygodniach suplementacji kwasami omega-3 w dawce 1,8 g/dobę u blisko połowy pacjentów stwierdzono redukcję PASI o 50\% [92]. Nie wszystkie dane są jednak spójne, choćby w kwestii wpływu na redukcję poszczególnych składowych w skali PASI albo też efektywności suplementacji $[82,93]$.

\section{PODSUMOWANIE}

Znaczenie lipidów w patogenezie łuszczycy jest niezaprzeczalne. Wpływają one na powiązania łuszczycy z chorobami ogólnoustrojowymi i zaburzeniami immunologicznymi. Niezbędna jest wielospecjalistyczna diagnostyka pod kątem występowania czynników ryzyka wystąpienia CVD, zwłaszcza otyłości i jej następstw metabolicznych, u chorych na łuszczycę. Ważne są wczesne podjęcie działań terapeutycznych i edukacyjnych w celu wprowadzenia prozdrowotnego stylu życia, leczenie farmakologiczne zaburzeń gospodarki lipidowej i węglowodanowej. Nie należy pomijać diety jako ważnego elementu profilaktyki i kompleksowego leczenia pacjentów z łuszczycą.

\section{KONFLIKT INTERESÓW}

Autorzy deklarują brak konfliktu interesów.

\section{CONFLICT OF INTEREST}

The authors declare no conflict of interest.

\section{References}

\section{Piśmiennictwo}

1. Limaye K.: Psoriasis: an overview and update. Nurse Pract 2015, 40, 23-26.

2. Ryan C., Kirby B.: Psoriasis is a systemic disease with multiple cardiovascular and metabolic comorbidities. Dermatol Clin 2015, 33, 41-55.

3. Malkic Salihbegovic E., Hadzigrahic N., Cickusic A.: Psoriasis and metabolic syndrome. Med Arch $2015,69,85-87$.

4. Farley E., Menter A.: Psoriasis: comorbidities and associations. G Ital Dermatol Venereol 2011, 146, 9-15.

5. Owczarczyk-Saczonek A., Nowicki R.: Patofizjologia związków łuszczycy z zaburzeniami metabolicznymi. Przegl Dermatol 2013, 100, 125-131 
6. Boehncke W.H., Boehncke S., Tobin A.M., Kirby B.: The "psoriatic march": a concept of how severe psoriasis may drive cardiovascular comorbidity. Exp Dermatol 2011, 20, 303-307.

7. Wilkinson D., Farber EM.: Fatty acids of surface lipids from uninvolved skin in psoriasis. J Invest Dermatol 1967, 49, 526-532.

8. Meffert H., Geschwendt G., Reich P.: Cholesterol and cholesterol ester in the surface lipid of psoriasis patients. Dermatol Monatsschr 1969, 155, 162-168.

9. Pietrzak A., Michalak-Stoma A., Chodorowska G., Szepietowski J.: Lipid disturbancies in psoriasis: an update. Mediators Inflamm 2010, 2010, 535-612.

10. Feingold K.R.: Thematic review series: skin lipids. The role of epidermal lipids in cutaneous permeability barrier homeostasis. J Lipid Res 2007, 48, 2531-2546.

11. Vaccaro M., Pergolizzi S., Mondello M.R., Santoro G., Cannavò S.P., Guarneri B., et al.: The dermoepidermal junction in psoriatic skin as revealed by scanning electron microscopy. Arch Dermatol Res 1999, 291, 396-399.

12. Motta S., Monti M., Sesana S., Mellesi L., Ghidoni R., Caputo R.: Abnormality of water barrier function in psoriasis. Role of ceramide fractions. Arch Dermatol 1994, 130, 452-456.

13. Khyshiktuev B.S., Falko E.V.: Alterations in the parameters of lipid metabolism in different biological objects in psoriatic patients during exacerbation and remission. Vestnik Dermatologii Venerologii 2005, 6, 40-43.

14. Fortinskaia E.S., Torkhovskaia T.I., Sharapova G., Loginova T.K., Kliuchnikova Z., Khalilov E.M.: Features of distribution of free and esterified cholesterol in the epidermis, biological membranes and plasma lipoproteins in psoriasis. Klin Lab Diagn $1996,4,38-43$

15. Tekin N.S., Tekin I.O., Barut F., Sipahi E.Y.: Accumulation of oxidized low-density lipoprotein in psoriatic skin and changes of plasma lipid levels in psoriatic patients. Mediators Inflamm 2007, 2007, 78454.

16. Grøn B., Iversen L., Ziboh V., Kragballe K.: Monohydroxy fatty acids esterified to phospholipids are decreased in lesional psoriatic skin. Arch Dermatol Res 1993, 285, 449-454.

17. Khyshiktuyev B., Karavayeva T., Falko Y.: Variability of quantitative changes in short-chain fatty acids in the serum and epidermis in psoriasis. Klin Lab Diagn 2008, 8, 22-24.

18. Choromańska B., Myśliwiec P., Dadan J., Hady R.H., Chabowski A.: Znaczenie kliniczne białek wiążących kwasy tłuszczowe. Postepy Hig Med Dosw 2011, 65, 759-763.

19. Dallaglio K., Marconi A., Truzzi F., Lotti R., Palazzo E., Petrachi T., et al.: E-FABP induces differentiation in normal human keratinocytes and modulates the differentiation process in psoriatic keratinocytes in vitro. Exp Dermatol 2013, 22, $255-261$.

20. Miyake T., Ogawa E., Mikoshiba A., Kobayashi A., Hosoe H., Kashiwabara S., et al.: Epidermal-type FABP is a predictive marker of clinical response to systemic treatment and ultraviolet therapy in psoriatic skin lesions. J Dermatol Sci 2012, 68, 199-202.

21. Myśliwiec H., Baran A., Harasim-Symbor E., Choromańska B., Myśliwiec P., Milewska A.J., et al.: Increase in circulating sphingosine-1-phosphate and decrease in ceramide levels in psoriatic patients. Arch Dermatol Res 2017, 309, 79-86.

22. Borodzicz S., Rudnicka L., Mirowska-Guzel D., Cudnoch-Jedrzejewska A.:. The role of epidermal sphingolipids in dermatologic diseases. Lipids Health Dis 2016, 15, 13.

23. Lew B.L., Cho Y., Kim J., Sim W.Y., Kim N.I.: Ceramides and cell signaling molecules in psoriatic epidermis: reduced levels of ceramides, PKC-alpha, and JNK. J Korean Med Sci 2006, 21, 95-99.

24. Moon S.H., Kim J.Y., Song E.H., Shin M.K., Cho Y.H., Kim N.I.: Altered levels of sphingosine and sphinganine in psoriatic epidermis. Ann Dermatol 2013, 25, 321-326.

25. Nakajima K., Terao M., Kataoka S., Goto-Inoue N., Setou M., Horie K., et al.: Barrier abnormality due to ceramide deficiency leads to psoriasiform inflammation in a mouse model. J Invest Dermatol 2013, 133, 2555-2565.

26. Cho Y., Lew B.L., Seong K., Sim W.Y., Kim N.I.: An inverse relationship between ceramide synthesis and clinical severity in patients with psoriasis. J Korean Med Sci 2004, 19, 859-863.

27. Checa A., Xu N., Sar D.G., Haeggström J.Z., Ståhle M.B., Wheelock C.E.: Circulating levels of sphingosine-1-phosphate are elevated in severe, but not mild psoriasis and are unresponsive to anti-TNF-alpha treatment. Sci Rep 2015, 5, 12017.

28. Alessandrini F., Stachowitz S., Ring J., Behrendt H.: The level of prosaposin is decreased in the skin of patients with psoriasis vulgaris. J Invest Dermatol 2001, 116, 394-400.

29. Sarvtin M., Hedayati M., Shokohi T., HajHeydari Z.: Serum lipids and lipoproteins in patients with psoriasis. Arch Iran Med 2014, 17, 343-346.

30. Tekin N., Tekin I., Barut F., Sipahi E.: Accumulation of oxidized low-density lipoprotein in psoriatic skin and changes of plasma lipid levels in psoriatic patients. Mediators Inflamm 2007, 2007, 78454.

31. Akhyani M., Ehsani A., Robati R., Robati A.: The lipid profile in psoriasis: a controlled study. J Eur Acad Dermatol Venereol 2007, 21, 1330-1332.

32. Veetil B., Matteson E., Maradit-Kremers H., McEvoy M., Crowson C.: Trends in lipid profiles in patients with psoriasis: a population-based analysis. BMC Dermatol 2012, 12, 20.

33. Uyanik D., Ari Z., Onur E., Gündüz K., Tanülkü S., Durkan K.: Serum lipids and apolipoproteins in patients with psoriasis. Clin Chem Lab Med 2002, 40, 65-68.

34. Pang X., Lin K., Zhang P., Zhu S.: Characterization of abnormal lipid profile in Chinese patients with psoriasis. Int J Clin Exp Pathol 2015, 8, 15284-1528.

35. Rocha-Pereira P., Santos-Silva A., Rebelo I., Figueiredo A., Quintanilha A., Teixeira F.: Dislipidemia and oxidative stress in mild and in severe psoriasis as a risk for cardiovascular disease. Clin Chim Acta 2001, 303, 33-39.

36. Xiao T., Yang C., Xiao Y., Song F.: Serum apolipoprotein levels of psoriatic patients with normal serum lipid levels. Chin Med Sci J 1997, 130, 224-228.

37. Mallbris L., Granath F., Hamsten A., Ståhle M.: Psoriasis is associated with lipid abnormalities at the onset of skin disease. J Am Acad Dermatol 2006, 54, 614-621.

38. Pietrzak A., Kądzielewski J., Janowski K., Roliński J., Krasowska D., Chodorowska G., et al.: Lipoprotein (a) in patients with psoriasis: associations with lipid profile and disease severity. Int J Dermatol 2009, 48, 379-387.

39. Leren T., Maartmann-Moe K., Thune P., Berg K.: Low density lipoprotein receptors in cultured skin fibroblasts from psoriasis patients. Clin Genet 1984, 25, 230-241. 
40. Sunitha S., Rajappa M., Thappa D.M., Chandrashekar L., Munisamy M., Revathy G., et al.: Comprehensive lipid tetrad index, atherogenic index and lipid peroxidation: surrogate markers for increased cardiovascular risk in psoriasis. Indian J Dermatol Venereol 2015, 8, 464-471.

41. Pietrzak A., Toruniowa B., Pietrzak B., Chwaluk J.: Lipid profile in psoriatic patients according to sex and age. Przegl Dermatol 1994, 81, 255-260.

42. Myśliwiec H., Baran A., Harasim-Symbor E., Myśliwiec P., Milewska A., Chabowski A., et al.: Serum fatty acid profile in psoriasis and its comorbidity. Arch Dermatol Res 2017, 309, 371-380.

43. Kosinska M., Liebisch G., Lochnit G., Wilhelm J., Klein H., Kaesser U., et al.: Sphingolipids in human synovial fluid - a lipidomic study. PLoS One 2014, 9, 91769

44. Furuhashi M., Hotamisligil G.S.: Fatty acid-binding proteins: role in metabolic diseases and potential as drug targets. Nat Rev Drug Discov 2008, 7, 489-503.

45. Kralisch S., Fasshauer M.: Adipocyte fatty acid binding protein: a novel adipokine involved in pathogenesis of metabolic and vascular disease? Diabetologia 2013, 56, 10-21.

46. Baran A., Świderska M., Bacharewicz-Szczerbicka J., Myśliwiec H., Flisiak I.: Serum fatty acid-binding protein 4 is increased in patients with psoriasis. Lipids 2017, 52, 51-60.

47. Kural B., Orem G., Vanizor B.: Evaluation of the atherogenic tendency of lipids and lipoprotein content and their relationship with oxidant-antioxidant system in patients with psoriasis. Clin Chim Acta 2003, 328, 71-82.

48. Rocha-Pereira P., Santos-Silva A., Rebelo I., Figueiredo A., Quintanilha A., Teixeira F.: Dislipidemia and oxidative stress in mild and in severe psoriasis as a risk for cardiovascular disease. Clin Chim Acta 2001, 303, 33-39.

49. Peluso I., Cavaliere A., Palmery M.: Plasma total antioxidant capacity and peroxidation biomarkers in psoriasis. J Biomed Sci 2016, 23, 52.

50. Lima A., Lima M., Marques C., Duarte A., Pita R., Pita M.: Peroxisome proliferator-activated receptor agonists (PPARs): a promising prospect in the treatment of psoriasis and psoriatic arthritis. An Bras Dermatol 2013, 88, 1029-1035

51. Hegazy R., Abdel Hay R., Shaker O., Sayed S., Abdel Halim D.: Psoriasis and metabolic syndrome: is peroxisome proliferator-activated receptor-gamma part of the missing link? Eur J Dermatol 2012, 22, 622-628.

52. Ellis C., Varani J., Fisher G.J., Zeigler M.E., Pershadsingh H.A., Benson S.C., et al.: Troglitazone improves psoriasis and normalizes models of proliferative skin disease: ligands for peroxisome proliferator-activated receptor-gamma inhibit keratinocyte proliferation. Arch Dermatol 2000, 136, 609-616.

53. Bongartz T., Coras B., Vogt T., Schölmerich J., Müller-Ladner U.: Treatment of active psoriatic arthritis with the PPAR gamma ligand pioglitazone: an open-label pilot study. Rheumatology (Oxford) 2005, 44, 126-129.

54. Neimann A.L., Shin D.B., Wang X., Margolis D.J., Troxel A.B., Gelfand J.M.: Prevalence of cardiovascular risk factors in patients with psoriasis. J Am Acad Dermatol 2006, 55, 829-835.

55. Gupta M., Chari S., Borkar M., Chandankhede M.: Dyslipidemia and oxidative stress in patients with psoriasis. Biomed Res 2011, 22, 221-224.

56. Komorowska O., Bohdan M., Szczerkowska-Dobosz A., Rawicz-Zegrzda D., Dudziak M., Zdrojewski T., et al.: Assessment of cardiovascular risk factors in patients with psoriasis. Acta Dermatovenereol Croat 2016, 24, $261-267$.

57. Mosca S., Gargiulo P., Balato N., Di Costanzo L., Parente A., Paolillo S., et al.: Ischemic cardiovascular involvement in psoriasis: a systematic review. Int J Cardiol 2015, 178, 191-199.

58. Mehta N., Azfar R., Shin D., Neimann A., Troxel A., Gelfand J.: Patients with severe psoriasis are at increased risk of cardiovascular mortality: cohort study using the General Practice Research Database. Eur J Heart 2010, 31, 1000-1006.

59. Wang X., Guo Z., Zhu Z., Bao Y., Yang B.: Epicardial fat tissue in patients with psoriasis: a systematic review and meta-analysis. Lipids Health Dis 2016, 15, 103.

60. Argote A., Mora-Hernández O., Milena Aponte L., Barrera-Chaparro D., Muñoz-Ruiz L., Giraldo-Mordecay L.: Cardiovascular risk factors and carotid intima-media thickness in a Colombian population with psoriasis. Actas Dermosifiliogr 2017, doi: 10.1016/j.ad.2017.04.015.

61. Baran A., Flisiak I., Chodynicka B.: Znaczenie wybranych adipokin w łuszczycy. Przegl Dermatol 2011, 98, $422-428$.

62. Baran A., Flisiak I., Jaroszewicz J., Świderska M.: Effect of psoriasis activity on serum adiponectin and leptin levels. Postep Dermatol Alergol 2015, 32, 101-106.

63. Baran A., Świderska M., Flisiak I.: Effect of topical treatment and psoriasis severity on serum retinol-binding protein-4 levels. J Dermatol Treat 2016, 27, 114-119.

64. Nakajima H., Nakajima K., Tarutani M., Morishige R., Sano S.: Kinetics of circulating cytokines and adipokines in psoriasis patients. Arch Dermatol Res 2011, 303, 451-455.

65. Romero-Talamás H., Aminian A., Corcelles R., Fernandez A., Schauer P., Brethauer S.: Psoriasis improvement after bariatric surgery. Surg Obes Relat Dis 2014, 10, 1155-1159.

66. Egeberg A., Sørensen J., Gislason G., Knop F., Skov L.: Incidence and prognosis of psoriasis and psoriatic arthritis in patients undergoing bariatric surgery. JAMA Surg 2017, 152, 344-349.

67. Kiluk P., Kiluk I., Baran A., Myśliwiec H., Flisiak I.: Występowanie zespołu metabolicznego u pacjentów z łuszczycą - analiza retrospektywna 302 przypadków. Derm Klin 2014, 16, 57-61.

68. Love T., Qureshi A., Karlson E., Gelfand J., Choi H.: Prevalence of the metabolic syndrome in psoriasis: results from the national health and nutrition examination survey, 2003-2006. Arch Dermatol 2011, 147, 419-424.

69. Kothiwala S., Khanna N., Tandon N., Naik N., Sharma V., Sharma S.: Prevalence of metabolic syndrome and cardiovascular changes in patients with chronic plaque psoriasis and their correlation with disease severity: a hospital-based cross-sectional study. Indian J Dermatol Venereol Leprol 2016, 82, 510-518.

70. Pereira R., Amladi S., Varthakavi P.: A study of the prevalence of diabetes, insulin resistance, lipid abnormalities, and cardiovascular risk factors in patients with chronic plaque psoriasis. Indian J Dermatol 2011, 56, 520-526.

71. Granata M., Skarmoutsou E., Trovato C., Rossi G., Mazzarino M., D'Amico F.: Obesity, type 1 diabetes, and psoriasis: an autoimmune triple flip. Pathobiology 2017, 84, 71-79. 
72. Carrascosa J., Rocamora V., Fernandez-Torres R., Jimenez-Puya R., Moreno J., Coll-Puigserver N., et al.: Obesity and psoriasis: inflammatory nature of obesity, relationship between psoriasis and obesity, and therapeutic implications. Actas Dermosifiliogr 2014, 105, 31-44.

73. Gisondi P., Del Giglio M., Girolomoni G.: Considerations for systemic treatment of psoriasis in obese patients. Am J Clin Dermatol 2016, 17, 609-615.

74. Malatjalian D., Ross J., Williams C., Colwell S., Eastwood B.: Methotrexate hepatotoxicity in psoriatics: report of 104 patients from Nova Scotia, with analysis of risks from obesity, diabetes and alcohol consumption during long-term follow-up. Can J Gastroenterol 1996, 610, 369-375.

75. Coimbra S., Oliveira H., Reis F., Belo L., Rocha S., Quintanilha A., et al.: Psoriasis therapy and cardiovascular risk factors: a 12-week follow-up study. Am J Clin Dermatol 2010, 11, 423-432.

76. Corbetta S., Angioni R., Cattaneo A., Beck-Peccoz P., Spada A.: Effects of retinoid therapy on insulin sensitivity, lipid profile and circulating adipocytokines. Eur J Endocrinol 2006, 154, 83-86.

77. No D., Amin M., Egeberg A., Wu J.: The role of biologic therapy for psoriasis in cardiovascular risk reduction. Cutis 2017, 99, 78-79.

78. Ports W., Fayyad R., DeMicco D., Laskey R., Wolk R.: Effectiveness of lipid-lowering statin therapy in patients with and without psoriasis. Clin Drug Investig 2017, 37, 775-785.

79. Ramessur R., Gill D.: The effect of statins on severity of psoriasis: a systematic review. Indian J Dermatol Venereol Leprol 2017, 83, 154-161.

80. Barrea L., Nappi F., Di Somma C., Savanell M., Falco A., Balato A., et al.: Environmental risk factors in psoriasis: the point of view of the nutritionist. Int J Environ Res Public Health 2016, 13, 743.

81. Owczarczyk-Saczonek A., Placek W.: Czy dieta w łuszczycy ma znaczenie? Przegl Dermatol 2014, 101, 319-326.

82. Stawczyk M., Szczerkowska-Dobosz A., Komorowska O., Dobosz M., Maciejewska-Radomska A.: Znaczenie diety w łuszczycy - przewlekłej układowej chorobie zapalnej. Forum Zaburzeń Metabol 2011, 2, 205-212.

83. Afifi L., Danesh M., Lee K., Beroukhim K., Farahnik B., Ahn R., et al.: Dietary behaviors in psoriasis: patient-reported outcomes from a U.S. National Survey. Dermatol Ther (Heidelb) 2017, 7, 227-242.

84. Upala S., Sanguankeo A.: Effect of lifestyle weight loss intervention on disease severity in patients with psoriasis: a systematic review and meta-analysis. Int J Obes (Lond) 2015, 39, 1197-1202.

85. Jensen P., Christensen R., Zachariae C., Geiker N., Schaadt B., Stender S., et al.: Long-term effects of weight reduction on the severity of psoriasis in a cohort derived from a randomized trial: a prospective observational follow-up study. Am J Clin Nutr 2016, 104, 259-265.

86. Bhatia B., Millsop J., Debbaneh M., Koo J., Linos E., Liao W., et al.: Diet and psoriasis, part II: celiac disease and role of a gluten-free diet. J Am Acad Dermatol 2014, 71, 350-358.

87. Michaelsson G., Gerdén B., Hagforsen E., Nilsson B., Pihl-Lundin I., Kraaz W., et al.: Psoriasis patients with antibodies to gliadin can be improved by a gluten-free diet. Br J Dermatol 2000, 142, 44-51.

88. Farkas A., Kemény L.: Alcohol, liver, systemic inflammation and skin: a focus on patients with psoriasis. Skin Pharmacol Physiol 2013, 26, 119-126.

89. Sicińska P., Pytel E., Kurowska J., Koter-Michalak M.: Suplementacja kwasami omega w różnych chorobach. Postepy Hig Med Dosw 2015, 69, 838-852.

90. Rahman M., Beg S., Ahmad M., Kazmi I., Ahmed A., Rahman Z., et al.: Omega-3 fatty acids as pharmacotherapeutics in psoriasis: current status and scope of nanomedicine in its effective delivery. Curr Drug Targets 2013, 14, 708-722.

91. Guida B., Napoleone A., Trio R., Nastasi A., Balato N., Laccetti R., et al.: Energy-restricted, n-3 polyunsaturated fatty acids-rich diet improves the clinical response to immuno-modulating drugs in obese patients with plaque-type psoriasis: a randomized control clinical trial. Clin Nutr 2014, 33, 399-405.

92. Adil M., Singh P., Maheshwari K.: Kliniczna ocena działania kwasów tłuszczowych omega-3 w leczeniu łuszczycy. Przegl Dermatol 2017, 104, 314-323.

93. Bjorneboe A., Smith A., Bjorneboe G.: Effect of dietary supplementation with n-3 fatty acids on clinical manifestations of psoriasis. Br J Dermatol 1988, 20, 77-83.

Received: 31.07.2017

Accepted: 9.09.2017

Otrzymano: 31.07.2017 r.

Zaakceptowano: 9.09.2017 r.

How to cite this article

Baran A., Kiluk P., Myśliwiec H., Flisiak I.: The role of lipids in psoriasis. Dermatol Rev/Przegl Dermatol 2017, 104, 619-635. DOI: https://doi.org/10.5114/dr.2017.71834. 